\title{
Sinemada Korkunun Verdiği Hazzın Yüce Kavramı ile Açıklanması ve Antonio Margheriti'nin Danza Macabra (1964) Filmi
}

\author{
Frrat Osmanoğulları*
}

\section{Özet}

Sinemada, özellikle de korku sinemasında, doğrudan korku hissi üretmeye yönelik imajlar bulunabilmekle birlikte, korku hissi tek bir imaj, sahne ya da sekans içerisinde yer almayabilir de. Türlü sinematografik tekniklerle tek başına 'negatif' hisler uyandırmayacak imajlar ya da işitsel sinematik unsurlar da korku verici hale gelebilir. Her ne şekilde üretilmiş olursa olsun, bir filmdeki korku dolu anlar seyirci tarafindan estetik bir haz talebi ile seyredilir.

Bir filmde üretilen korku, dehşet ve acı gibi negatif hislerin seyirciye verdiği hazzı anlamlandırabilmek adına bu çalışmada 'yüce' kavramına başvurulacaktır. Özellikle Burke ve Kant'ın yaklaşımlarından yararlanılarak tartışılacak yüce kavramı, bu hazzı açıklamaya imkân vermektedir. Aynı zamanda bir filmin hangi sinematik unsurlar kullanarak yüce etkisini yaratma yetisi de tartışılacaktır. Bütün bu tartışmalar, bu çalışmada, İtalyan yönetmen Antonio Margheriti'nin Danza Macabra (1964) filminin örnek çözümlemesi üzerinden gerçekleştirilecektir.

Anahtar sözcükler: Korku, Haz, Yüce, Danza Macabra.

\footnotetext{
*ORCID: 0000-0003-2669-7558
}

E-mail: firatosmanogullari@gmail.com

DOI: $10.31122 /$ sinefilozofi.688556

Geliş Tarihi - Recieved: 12.01.2020

Kabul Tarihi - Accepted: 14.01.2020 


\title{
Analysing the Pleasure of Horror in Cinema with the Concept of 'Sublime' and Antonio Margheriti's Danza Macabra (1964)
}

\author{
Firat Osmanoğullar1*
}

\begin{abstract}
Especially horror movies, there may be images that directly cause the feeling of fear, but thisfeeling of fear may not be only in a single image, scene or sequence. Images and audio cinematic elements that can't produce 'negative' feelings by itself can also become frightening with various cinematographic techniques. No matter how it is produced, the audience watch fearful moments in movies with an aesthetic demand for pleasure.

Within the scope of this study, I will use the concept of 'supreme' for analysing the negativefeelings of fear, horror and pain caused by the movies. I will discuss the concept of the supreme by taking advantage of Burke and Kant's approaches. I believe it provides a suitable framework to examine this aesthetic pleasure. At the same time, I will also discuss a film's ability to create sublime effect using cinematic elements. In this study, I will carry out all these discussions through the analysis of the Italian director Antonio Margheriti's Danza Macabra (1964) movie.
\end{abstract}

Keywords: horror, pleasure, sublime, Danza Macabra.

*ORCID: 0000-0003-2669-7558

E-mail: firatosmanogullari@gmail.com

DOI: 10.31122/sinefilozofi.688556

Received - Geliş Tarihi: 12.01.2020

Accepted - Kabul Tarihi: 14.03.2020 


\section{Giriş}

Korku filmlerinin ya da filmlerdeki korkutucu, tiksindirici, dehşet verici imajların nasıl oluyor da estetik bir haz talebi ile seyredildiği üzerine bir tartışma yapmak bu çalışmanın esas meselesidir. Bu hazzın kabaca sadist bir duruma işaret ettiğini söylemek haksızlık olmakla birlikte, indirgemeci ve abartılı bir tutum da olacaktır. Şu bir gerçek ki, korku filmlerinin hatırı sayılır bir seyirci kitlesi var ve seyirci bu filmleri seyrederken hem korkuyor hem de bu korkudan dolayı bir hoşlanma duygusuna kapılıyor. Örneğin, Scognamillo korku filmi seyircisinin bu anlamda, "eskiden idamları ve işkenceleri izleyebilmek için meydanlara dökülen, alkış tutan, heyecanlanan, bayram eden kalabalıklarla" oldukça benzer olduğunu söyler (Scognamillo, 2006: 11). Korku, dehşet ve acı hissinin yarattığı bu haz irdelenmeye; dahası anlamlandırılmaya değerdir. Bu çalışmada sinemada korkunun verdiği haz duygusunun sebebi ve bunu hangi sinematik unsurlara başvurarak gerçekleştirdiği meselesi "yüce" kavramı üzerinden anlaşılmaya çalışılacaktır. Kavramın tarihsel geçmişi çok öncelere dayansa da, kapsamlı ve sistematik olarak önce Edmund Burke, ardından da Immanuel Kant' 1 tartıştığı yüce kavramı korku, acı ve dehşet gibi ‘negatif' hislerin, aynı zamanda estetik bir hoşlanma duygusu yaratabileceği meselesi üzerinde durmaktadır. Dolayısıyla korku filmlerinde bu negatif hisleri uyandıran imajlar, ses kullanımı gibi sinematik unsurların yarattığı hoşlanma ya da haz duygusunu anlamak adına yüce kavramı oldukça kullanışlı olabilir. Kuşkusuz bu mesele başkaca yaklaşımlar üzerinden de ele alınabilir. Söz gelimi bir alan araştırması yapılabilir ve seyircinin verdiği yanıtlar toplanarak, bunlar üzerinden bir sonuca ulaşılabilir. Ya da psikanalitik kuram da bu meseleyi anlamak için kullanılabilir. Kaldı ki bu tarz çalışmalar akademik literatürde bolca mevcut. Bu çalışmalarda çoğunlukla bilinçaltının bilinci film süresi boyunca birkaç saatliğine alt etmesinin verdiği haz üzerinde durulduğu görülür. Özellikle Ünsal Oskay'ın Çağdaş Fantazya kitabında, korku filmlerinin psikanalitik kuram ve kavram setleri ile bu çerçevede ele alınışnın oldukça yetkin bir örneği, henüz film çalışmalarında psikanalitik kuramın bu kadar yaygınlaşmadığı erken bir dönemde sunulmuştur. ${ }^{1}$ Hangi konumlanma noktasina yerleşilirse yerleşilsin, sinemada korku, dehşet ve acı hissinin aynı zamanda hoşlanma ve haz duygusu yaratması ilk bakışta paradoksal görünmekle birlikte, tam da bu sebeple ilgi çekicidir de. Yüce kavramı ise, bize bunun aslında bir paradoks olmanın daha ötesinde bir durum olduğunu anlamakta yol göstericidir.

Bu doğrultuda, çalışmanın ilk bölümünde yüce kavramı üzerine bir tartışma yürütülecektir. Bu kapsamda, ilk olarak Burke'ün yüce kavramı üzerine görüşlerine yer verilerek, onun yaklaşımı bağlamında yücenin hissinin kaynakları ve oluşum süreci ele alınacaktır. Ardından yüceyi 'negatif haz' olarak ele alan Kant'ın yüce kavrayışı ve yarattığı matematik yüce ile dinamik yüce kavramları açıklanmaya çalışılacaktır. Yüce kavramı üzerine olan tartışmanın, film analizi bölümünden önce yapılmasının amacı, yüce kavramının ve onunla ilişkili diğer kavram setlerinin karşılığını, örnek olarak belirlenmiş filmde aramak ya da onları somutlaştırmak değildir. Başka bir deyişle, seçilen film, yüce kavramını doğrulamak adına belirlenmiş bir örneklem ya da bir veri kaynağı olarak düşünülmemelidir. Tam tersine,

\footnotetext{
${ }^{1}$ Oskay'ın (2014) adı geçen çalışmasında, özellikle korku sinemasından örneklere yer verdiği birinci bölüm
} psikanalitik kuram çerçevesinde korkunun bilinç ve bilinçaltı ile ilişkisini ele alış biçimi açısından ilgi çekicidir. 
korku sinemasının, korkutmak için başvurduğu sinematik unsurların yarattığı korku, dehşet ve acı hissi ile bu hissin beraberinde getirdiği estetik haz meselesini açıklayabilmek ve anlamlandırabilmek adına yerleşilecek konumlanma noktasını ve kullanılacak kavram setlerini oluşturabilmek için önce yüce kavramı tartışmasına yer verilmesi tercih edilmiştir.

Yüce kavramı üzerine yapılacak tartışmanın ardından, korku filmlerinin yüce hissini nasıl oluşturduğunu anlayabilmek için İtalyan yönetmen Antonio Margheriti'nin Danza Macabra (Ölüm Dansı, 1964) filmi incelenecektir. Bu inceleme sirasında, korku filmleri söz konusu olduğunda yüce hissinin iki şekilde gerçekleştiği öne sürülecektir. Bunlardan ilki, sinemada ya da ekran başında, pratik/gündelik evren içerisindeki seyirci ile filmik evrendeki karakterin bir yere kadar ortaklaştığı, ardından bu ortaklığın bozulup sadece sinemadaki ya da ekran başındaki seyircinin devam ettirebilme imkânı bulduğu yüce hissi, ikincisi ise bir takım sinematik araçlarla üretilen yüce hissi olacaktır.

\section{Yüce Kavramı Üzerine}

\section{Burke'ün Yüce Kavrayışı ve Yüce Hissinin Oluşum Süreçleri}

Edmund Burke, 1757 yılında yazmış olduğu Yüce ve Güzel Kavramlarımızın Kaynă̆ı Hakkında Felsefi Bir Soruşturma adlı eserinde, yüce ve güzel kavramlarının, insanın hangi etkileşimlerinden ve duyumlarından kaynaklandığını ve hangi hislerin üretilmesi ile ilgili olduğunu detaylı olarak açıklamaya girişir. Burke'e göre, "Acı ve tehlike düşüncesini uyandırmaya uygun her tür şey, başka bir deyişle, herhangi bir biçimde korkunç olan ya da korkunç nesnelerle bağlantılı olan veya dehşete benzer bir etki yaratan her şey yücenin kaynağıdır" (Burke, 2008: 42). Ancak yüce olarak adlandırılan şey nesnenin kendisi değildir. Burke burada yüce bir nesneden değil; acı, tehlike, korku ya da dehşet uyandıran nesnenin yüce bir etkiye yol açtığından söz eder. Aynı zamanda Burke için, acı hissi zihnin hissedebileceği en güçlü duygudur ve yüce de bu en güçlü duyguları açığa çıkarır. Dahası, korku ve acı hissinin yarattığ1 etki Burke'e göre, herhangi bir hazzın etkisinden daha yoğundur (Burke, 2008: 42-43). Burke'ün yaklaşımında yüce hissinin ortaya çıkması için iki aşamalı bir durumun söz konusu olduğu söylenebilir. İlk olarak; yüce hissinin ortaya çıkabilmesi için öznenin karşılaşma yaşadığı korku ve dehşet hissi uyandıran nesne ya da olay karşısında haz duyması gerekmektedir. Başka bir deyişle, korku ve acı hissinin haz verdiği anlar ancak yüce ile ilişkilendirilebilir. Ancak bu hazzın olmazsa olmaz bir koşulu vardır. Bu da bizi, bir tür 'mesafelilik ilkesi' olarak da adlandırılabilecek ikinci aşamaya götürür. Burke şöyle der: "Tehlike ya da acı çok yakındaysa, hiç keyif vermezler ve yalnızca korkuturlar ama belli mesafelerden ve çeşitli biçimlerde değişikliğe uğrayarak, her gün yaşadığımız üzere, keyif verebilirler, nitekim verirler de" (Burke, 2008: 43). Görüldüğü üzere Burke burada yücenin kaynaklandığı korku ve dehşet hissi ile salt korku ve dehşet hissi arasında net bir ayrım yapar: "Dehşet ensemizde hissetmediğimiz müddetçe her zaman için keyif veren bir tutkudur" (Burke, 2008: 48). Bu iki aşamayı daha iyi anlamak için Thomas De Quincey'nin Güzel Sanatlarn Bir Dalı Olarak Cinayet adlı eserine bakmak faydalı olabilir.

De Quincey'nin, konferans metni tarzında yazılmış 3 denemeden oluşan, 1827 ile 1854 yılları arasında yazmış olduğu Güzel Sanatların Bir Dah Olarak Cinayet adlı eseri, Burke'ün yüce 
hissini ortaya çıkaran aşamaları somutlaştırmak adına iyi bir örnek teşkil eder. Öncelikle, metnin ismi ve içeriği oldukça provakatif olmasına rağmen, De Quincey üçüncü denemede eserinin nüktedan bir amaçla yazıldığını, "sabun köpüğü bir eğlence" işi olarak düşünülmesi gerektiğini belirtir (De Quincey, 2013: 86). De Quincey'e göre bir cinayete 2 açıdan yaklaşılabilir: ahlaki ve estetik olarak. Ahlaki yaklaşım, bir cinayetin olmadan önceki hali ile ilgilidir. Eğer böyle bir şüphe varsa kuşkusuz onu engellemek için her şeyi yaparı. Ama olmuş bitmiş bir cinayet söz konusuysa orada artık ahlak bir kenara çekilmeli, beğeni ilkesi devreye girmelidir. Burada artık estetik bir performans olarak öldürme eylemi değerlendirilir (De Quincey, 2013: 23-26). Hatta cinayetler arasında karşılaştırma bile yapılabilir; tıpkı bir sanat eseri gibi. Kasap işi ya da zarafet dolu vb. (De Quincey, 2013: 64-66). De Quincey'nin ahlaki yaklaşımı, büyük ölçüde, Burke'ün yaklaşımındaki yüce hissinin ortaya çıkması için gerekli olan birinci aşamaya tekabül eder. Bir cinayetin oluş anına tanık olmak kuşkusuz salt korku, acı ve dehşet hissi ile ilgilidir. Bir cinayeti olup bittikten sonra ele almak, yani estetik yaklaşım ise ikinci aşama, yani mesafelilik ilkesi ile ilgilidir. Artık ensemizde hissettiğimiz bir korku, acı ve dehşet hissi yoktur. Dolayısıyla De Quincey'nin ölçütleri içerisinde bir cinayeti artık, belirli bir mesafeden olmak koşuluyla, estetik ilkelere göre ele alabilmek mümkün hale gelir.

Aslında yüce kavramı üzerinden Burke de bir cinayetin, bir felaketin, acı ve tehlike uyandıran bir durumun nasıl oluyor da seyirlik bir hale gelebildiğini ve estetik bir haz yaratabildiğini anlamaya çalışmaktadır. Burke şöyle der: "Kendini koruma ile ilgili tutkular acı ve tehlikeye dayanır; bunların nedenleri bizi doğrudan etkiliyorlarsa bu tutkular yalnızca acı verirler; aslında acı ve tehlike altında olmamamıza rağmen, acı ve tehlike fikrini ediniyorsak o zaman bu tutkular keyif vericidir" (Burke, 2008: 54). İşte bu keyif hissini yaratan her şey yücedir. Burke burada mesafelilik ilkesinin yarattığ güvenli bölgenin imkân verdiği bir beğeni ilkesine vurgu yaparken, aynı zamanda bu beğeni ile iç içe geçmiş bir kendini sakınma ya da koruma olgusundan söz etmektedir. Mesafelilik ilkesi ifadesiyle anlatmak istediğimiz, özetle böyle bir ilişkiye karşılık gelmektedir.

Bununla birlikte Burke'te yüce, sadece korku ve dehşet ile ilgili değildir. Söz gelimi, sonsuzluk hissi de yücenin başka bir kaynağıdır: "Göz birçok şeyin sınırlarını algılayamadığı için, bunlar sonsuzmuş gibi görünür ve gerçekten öyleymiş gibi bir etki yaratır" (Burke, 2008: 77). Ayrıca yüce sadece görme duyusu ile ilişkili değil, işitme gibi diğer duyularla da ilişkilidir. Sessiz bir gecede aniden duyulan dev bir saatin vuruş sesi ya da alçak, titrek ama belirli aralıklarla tekrarlayan tik-taklar da korku ve dehşet hissi uyandırma potansiyeline sahiptir ve bu hisler de yücenin ortaya çıkmasına sebep olabilmektedir (Burke, 2008: 87).

Son olarak, Burke yüce ve güzel olan arasında keskin bir ayrıma giderek, estetik kategorideki haz ve beğeni ilkelerini güzel olan içerisine hapsetmez. Güzel ile yüce arasında sadece haz talebi konusunda bir ortaklık söz konusudur. 'Yüce'nin temeli büyük ve korkutucu, dehşet verici nesne ve olaylardır; hayranlık hissi uyandırır. 'Güzel' ise küçük ve hoşa giden şeylerde kendisini gösterir; mutlak hazza yöneliktir ve sevgi hissi uyandırır (Burke, 2008: 163). Aynı zamanda 'yüce', rasyonel olarak kavranamayacak düzeyde aşırılık veya fazlalık sunarken, 'güzel' olan kavranabilirdir (Botting, 1996: 26). Her ne kadar Burke'ün yüce 
ile güzel arasında yaptığı ayrım büyük ölçüde yüzeysel dayanaklara sahipse de, en nihayetinde Burke yüce kavramını, 'güzel'in karşıtı olan 'çirkin' (korku, dehşet ve acı hissi yaratabilecek bir çirkinlik olması koşuluyla) ile özdeşleştirir (Burke, 2008: 123).

\section{Kant'ın Negatif bir Haz Olarak Yüce'si, Matematik Yüce ve Dinamik Yüce}

Burke'ten sonra, yüce kavramı üzerine düşünen bir diğer önemli filozof ise Immanuel Kant olmuştur. Kant yüce kavramını ilk olarak 1764 yılında yayımlanmış olan Güzellik ve Yücelik Duyguları Üzerine Gözlemler adlı eserinde ele almıştır. Bu çalışması aslında Burke'ün yedi sene önceki çalışması ile hem ismen hem de içerik olarak büyük benzerlik taşımaktadır. Bununla birlikte metin, alışkın olduğumuz yoğun bir Kant metni olmaktan çok, gündelik bir dille yazılmıştır. Kant’ın bu kitabında yüce ve güzel meselelerini ele alırken Burke'ün yaklaşımını dayanak noktası olarak belirlediği söylenebilir. Her ne kadar korkutucu yücelik, soylu yücelik ve de görkemli yücelik gibi üç farklı yüce kategorisi belirlese de (Kant, 2017: 51), Kant'in bu metinde sistematik bir yaklaşım sunduğunu söylemek pek mümkün değildir. Ancak Kant asıl olarak yüce kavramını felsefi, kapsamlı ve sistematik olarak 1790 yılında Yargı Yetisinin Eleştirisi'nde ele alacaktır.

Filozof Gilles Deleuze, Kant'in yüce kavramını açıklamak için işe önce onun sentez anlayışını ortaya koyarak başlar. Deleuze'e göre, Kant'ın sentezini oluşturan üç işlemden bahsedilebilir. Bu işlemlerin ilki, Deleuze'ün parçaların kavranmasının ardışık sentezi olarak adlandırdığı süreçtir. Bu işlemde göz zamanda ve mekânda mevcut şeyin parçalarını onu kat ederek algılar. İkinci işlem ise yeniden-üretim sentezi olarak adlandırılır. Bu işlemde, kat etme işlemi sırasında sonraki parçaya geçildiğinde bir önceki parçayı her defasında yenidenüretmek gereklidir. Yani, öncekileri sonrakilerden hareketle yeniden üretmek zorunludur. Sentezin üçüncü ve son işlemi ise tanımdır. Bilinmeyeni, herhangi bir şey olanı ikame eden onun nesnesidir; tanımıdır. Birinci ve ikinci işlemler mekânsal ve zamansal bir biçimken üçüncü işlem onları kavramsal bir biçime taşır; yani tanım'ına (Deleuze, 2007: 89-94). O halde sentez düşüncesi olağan bir alımlama durumudur; bir şeyi normal ya da sapma olmadan algılama halidir. Ancak bu olağan alımlama durumu, normal ya da sapma olmadan algılama hali kimi zaman sekteye uğrar. Ardışık parçaların kavranamaz oluşu, bir sonraki parçada bir öncekinin yeniden üretilememesi ve onun tanımına ulaşılamaması ya da herhangi bir kavramsal biçime ulaşılamaması hali, Deleuze' ün belirttiği gibi Kant'ın düşüncesinde yücenin ortaya çıktığı anlardır (Deleuze, 2007: 97).

Kant'ta da yüce Burke'teki gibi estetik bir kategoridir ve Burke için olduğu gibi, Kant için de güzel ile arasındaki tek ortaklık ikisinin de haz duygusunu talep etmeleridir. Bununla birlikte, Kant'ın ayırt edici olduğu noktalardan en önemlisi, yüce için negatif haz tabirini kullanmasıdır. Kant'a göre, hoşlanma duygusu güzel söz konusu olduğunda olumlu bir hazza karşılık gelirken, yüce söz konusu olduğunda negatif bir haz duygusu yaratır (Kant, 2016: 72). Güzel söz konusu olduğunda ortaya çıkacak olumlu haz duygusu aynı zamanda Tunalı'ya göre, özne ile nesne arasındaki bir uyumu da beraberinde getirir. Bu uyum ise öznenin yaşam gücünde bir canlılık yaratır. Ancak yüce ile özdeşleşen negatif haz duygusu nesne ile özne arasında bir uyumsuzluk yaratır ve bu sayede öznede canlılığın engellendiği bir durum ortaya 
çıkar (Tunalı, 2010: 227). Dolayısıyla, yüceden kaynaklı haz dolaylı bir şekilde ortaya çıkar. Dahası hoşnutsuzluk gibi bir dayanak noktası söz konusudur. Yüce karşısında zihin, yüceyi uyandıran nesne ile gerçekleştirdiği karşılaşmada salt bir cezbedilme içinde değildir. Zihin aynı zamanda itilir. Kant'a göre, yüceden duyulan haz negatif bir haz olması tam olarak bununla ilgilidir. Bununla birlikte, yüce söz konusu olduğunda "hoşlanma, nesnenin görünüşünden ötürü değil, nesnenin görünüşüne rağmen ortaya çıkar (Altuğ, 2007: 238-240).

Kant, yüce hissinin kaynaklandığı iki durum saptar. Bunlardan ilki büyüklük ikincisi ise güçtür. Buradan hareketle Kant, iki farklı yüce kavrayışı geliştirir: Matematik Yüce ve Dinamik Yüce. Matematik yüce büyüklük ile ilgiliyken, dinamik yüce güç ile ilgilidir. Altuğ' un ifadesiyle, "Matematik yüce, doğadaki sonsuz (mutlak) büyüklüğün, dinamik yüce ise doğadaki ezici gücün estetik değerlendirilmesi ile ilişkilidir" (Altuğ, 2007: 242).

Kant'a göre matematik yüce mutlak bir büyüklüktür; büyüklük olarak hiçbir kıyaslamaya dâhil edilemez. O her şeyden büyüktür; kendisinden başka hiçbir şeye eşit değildir. Ondan başka her şey küçüktür (Kant, 2016: 74-76). Özne böyle bir doğa nesnesi ile yaşamış olduğu karşılaşmada, o nesneyi sonsuzmuşçasına algılar; böylesi sonsuz bir büyüklüğe sahip olduğu hissine kapılır. O halde matematik yüce, herhangi bir ölçülebilirliği veya sınırlılığı aşan, mutlak, kavranamayan bir büyüklük hissiyle ilgilidir. Ferry'nin belirttiği gibi Kant, Roma'daki Saint-Pierre Kilisesi'ne ilk defa giren bir gözlemcinin bu karşılaşma sonucunda bir tür huzursuzluk hissine kapıldığını belirtir. Gözlemci mekânın bütünlügüunü kavrayamaz; "bir bütün İdesini tasarlamaktaki acizliğini hisseder". Hayal gücü artık sınırlarına erişmiştir. Kendi hayal gücünü aşmaya çalışmasına rağmen başarısız olur. Onun başına gelen bir tür yetersizlik hissidir (Ferry, 2012: 139). Bu anda sentez işlemi artık gerçekleşemez; Deleuze'ün daha önce belirtmiş olduğu, sentezin üç aşaması işlemez. İşte bu anda matematik yüce ortaya çıkmıştır. Bütün bu başarısızlığa ve yetersizlik hissine rağmen bir haz duyma durumu söz konusudur. Bu haz, doğrudan sonsuzmuş gibi görünen nesneden kaynaklanmaz. Özne, burada nesnenin gerçek varoluşunu kavrayamasa da, onun sadece büyüklüğü onda bir haz duygusu meydana getirir. Bu haz duygusunu ya da hoşlanma durumu yaratan ise, nesnenin seyredilmesidir (Altuğ, 2007: 242-243). Her ne kadar matematik yücenin yarattığı haz öznenin yetersizliğinden ileri gelse de (kaldı ki Kant önceden de bahsedildiği üzere yüceyi negatif hoşlanma duygusu olarak belirtmişti), yücenin tam anlamıla bir başarısızlık durumu olduğu söylenemez. Bu durum hayal gücünün temsil edilemez karşısında sınırlarını deneyimlemesidir ve dolayısıyla burada gerçekleşen, aslında ileriye doğru bir sıçrayıştır. Kant şöyle der: “Verili sonsuzu (...) yalnızca düşünebilmek için bile insan anlığında kendisi duyulur üstü olan bir yeti gereklidir" (Kant, 2016: 79). Başka bir deyişle yüce, hayal gücünden daha güçlü bir yetinin; fikirler, ideler yetisinin ya da duyulur-üstü bir yetinin varlığını keşfettirir. (Deleuze, 2007: 99).

Dinamik yüce ise, korku yaratan bir güç ve bu korku hissine karşı bir direnç ile ilgilidir. Kant dinamik yüce ile ilgili olarak şunları söyler: “Doğa bizim tarafımızdan dinamik açıdan yüce olarak yargılanacaksa, korku yaratan olarak tasarımlanmalıdır (...) Direnç göstermeye çabaladı̆̆ımız şey bir kötülüktür; ve eğer yetilerimizi ona denk bulmazsak, bir korku nesnesidir. Bu nedenle estetik yargı için doğa ancak korku nesnesi olarak görüldügü düzeye 
dek güç olarak, öyleyse dinamik açıdan yüce olarak geçerli olabilir" (Kant, 2016: 83). Dolayısıyla tıpkı matematik yücede olduğu gibi dinamik yüce söz konusu olduğunda da öznede bir yetersizlik hissi ortaya çıkar. Dinamik yüce karşısında yaşanan bu yetersizlik hissi, öznede bir korku hissine de sebep olur. Karşılaşmanın yaşandığı doğa nesnesi artık bir korku nesnesidir. Öznenin bu korku nesnesi karşısında yaşadığı duygu ise dinamik yücedir. Kant, dinamik yüceyi yaratan doğa nesneleri ve olaylarını örneklendirirken, "her yeri altüst eden fırtınalar"dan, "kasırgalar" dan, "volkanlar" dan, "kabarıp köpüren okyanuslar" dan söz eder. Ancak burada, tıpkı Burke'ün yüce kavrayışında olduğu gibi bir ön koşul koyar: güvenlikli bir alanda olmamız (Kant, 2016: 84). Dolayısıyla Burke'te yüce hissinin ortaya çıkartan iki aşama; korku hissi ve 'mesafelilik ilkesi', Kant'ın dinamik yücesinde de benzer şekilde işler: korku hissi ve öznenin korku nesnesi karşısında güvenli bir alanda bulunması. Ancak Kant dinamik yüce kavrayışını daha ilerilere taşır. Şöyle ki, Altuğ'un da belirttiği gibi, özne korku yaratan doğa nesnesi karşısında kendisini aciz hisseder ve bu his onda aynı zamanda bir hoşnutsuzluk yaratır. Ancak, özne bu korku nesnesine karşı akılsal bir üstünlüğünün olduğunu fark ederek hoşnutsuzluğun yanında bir hoşlanma duygusu da yaşar. Böylece doğanın sahip olduğu korkutucu gücün üzerinde yükseldiğini hisseder ve aynı zamanda da yücenin kendi zihninde olduğunu keşfeder. Bu gücün öznede yarattığı hoşlanma duygusu ise, ancak yüksek bir bilinç ile mümkündür. İşte dinamik yüce, estetik anlamda özneyi kendi “yüksek beni" ile karşılaştırır; ilişkiye sokar (Altuğ, 2007: 260-262). Neticede Schiller'in de söylediği gibi, "yüce olanı hissedebilme yeteneği, insan tabiatının en mükemmel kabiliyetlerinden biridir" (Schiller, 2008: 222).

Edmund Burke ve Immanuel Kant'ın yüce kavramı üzerine yaklaşımları tartışıldıktan sonra, artık sinemada korku, dehşet ve acı hissi yaratan imaj, sahne ve sekansların yaşattığı haz duygusu, yani negatif haz, örnek film incelemesi Ölüm Dansı özelinde bu kavram ile açıklanmaya çalışılabilir.

\section{Örnek bir Film İncelemesi ve Korku Filmlerinde İmajlardan Yansıyan Yüceyi Hissetmek}

Ölüm Dansı, 1964 yılında, daha çok korku filmleriyle ünlü, İtalyan yönetmen Antonio Margheriti tarafından çekilmiştir ve dünyada Castle of Blood adıyla gösterilmiştir. Margheriti'nin ismi, filme uluslararası bir albeni katmak adına jenerikte Anthony Dawson olarak geçer. ${ }^{2}$ Yine jenerikte ve film afişinde filmin E. Allan Poe uyarlaması olduğu ifade edilmesine rağmen, Poe'nun bu isimde ve/veya bu anlatının uyarlanmış olabileceği bir öyküsü bulunmamaktadır. Aynı zamanda film, İtalyan yapımı ve İtalyanca olmasına rağmen,

\footnotetext{
${ }^{2}$ Bu taktiğe özellikle Avrupalı, düşük bütçeli filmler çeken birçok yönetmen başvurur. Söz gelimi, Odell ve Blanc'in da belirttiği gibi, İspanyol korku filmleri yönetmeni, oyuncu ve senarist Paul Naschy, asıl ismi Jacinto Molina olmasına rağmen, filmlerinin uluslararası alanda daha prestijli bir yer edinebilmesi adına bu ismi kullanmıştır (Odell, Blanc, 2011: 67-68).
} 
Viktorya dönemi Londra'sında geçer. ${ }^{3}$ Son olarak film, korku sinemasının bir alt türü olan gotik tarzda yapılmıştır. ${ }^{4}$

Bu kısa bilgilerin ardından, filmin incelenmesine geçmeden önce anlatıdan da kısaca bahsetmek, analizde yer verilecek imaj, sahne ve sekansları anlamlandırmak adına faydalı olacaktır. Alan Foster adında bir gazeteci Londra'ya geldiğini duyduğu Edgar Allan Poe ile röportaj yapmak istemektedir. Nihayet onu bir meyhanede otururken yakalar. Masada Poe ile birlikte, Lord Thomas Blackwood adında bir kişi daha vardır. Üçlü hayaletler, ölülerin dirilmesi gibi mistik konular üzerine konuşurlar. Seküler bir bakış açısına sahip Foster böyle hikâyelere inanmaz. Bunun üzerine Blackwood'un sahibi olduğu bir şatoda Foster'ın bir gece geçirip geçiremeyeceğine dair bahse tutuşurlar. Bu bahse göre Foster o gece şatoda kalmalıdır. Çünkü o gece 'ölüler gecesi' dir: Ölülerin ölümlerinin trajedisini yeniden yaşamak için şatoya döndükleri gece. Dahası, Blackwood'un söylediğine göre onunla daha önce bu konuda iddiaya giren hiç kimse şatodan sağ çıkamamıştır. Yine de Foster buna kulak asmaz ve şatoya gider. Şato terk edilmiş görünmektedir. Ancak zamanla şatoda başkalarının da olduğunu görür. Onlarla iletişime geçer; hatta sevişir. Önce bunların şatoda yaşayan insanlar olduğunu düşünse de, aslında bir zamanlar bu şatoda ölmüş olan hayaletler olduğunu anlaması uzun sürmez. Yine de buna bir türlü inanmak istemez. Korkuya kapılmaması konusunda kendisini sürekli telkin eder; sekülerliği ve rasyonel mantığ1 elden bırakmamak için kendisini zorlar. Ancak şatoda, eski sakinlerinin yaşadığı trajediye ve hepsinin farklı zamanlarda nasıl öldügüune, sanki o anlarda oradaymış̧asına, tanık olur. Farklı zaman boyutlarında gider gelir ve tüm cinayetler sanki yanı başında tekrar işlenir. Şatodakilerin onu da öldürmek istediğini de anlamıştır artık. Çünkü ölülerin tekrar dirilebilmeleri için yaşayanların kanını içmeleri gerekmektedir. Nihayetinde korku ve dehşet içerisinde şatodan kaçmaya uğraşsa da bunu başaramaz. $\mathrm{O}$ da farklı zamanlardaki diğer konuklar gibi öldürülür. Artık şatonun ölü sakinlerinden birisi haline gelmiştir.

Aslında Foster iddiayı kabul ederek kendini sınamak, sahip olduğu korku hissinin sınırlarını deneyimlemek, başka bir deyişle yüce bir deneyim yaşamak istemektedir. Onun için nasılsa hayaletler yoktur, ölülerin dirilmesi de mümkün değildir. Bir oyun gibi görür bu iddiayı. Zaten, filmin alttürünü niteleyen gotik kavramı da Scognamillo'nun belirttiği gibi, "insanın bilinmeyene ve doğaüstü sayılana karşı beslediği ilgi, bundan aldığı hazdır" (Scognamillo, 2014: 30). Foster da aslında bu ilgi ve hazzın peşindedir (tabii ki seyirci de). Şatoda henüz kimseyle karşılaşmamışken, elinde bir şamdanla mekânı gezer ve bize de gezdirir. Bahçeden itibaren Foster'ın başlıca gördükleri ve seyirci olarak bizim de onunla beraber gördüklerimiz şunlardır: kurumuş dallar, kara bir kedi, mezarlık. İçeri girdiğinde ise

\footnotetext{
3 Roberto Curti, İtalyan gotik korku filmlerini ele aldığı çalışmasında İtalyan gotik filmlerinin özelliklerini belirtirken hem bu uyarlama meselesine hem de mekân olarak İtalya dışının seçilmesine yer verir. Curti'nin vurguladığı gibi, İtalyan gotik filmleri büyük ölçüde serbest edebi uyarlamalardır ya da ‘öyle olduklarını iddia ederler'. Aynı zamanda birkaç istisna dışında bu filmler İtalya dışında, İtalyan yönetmenlerin ve diğer set görevlilerinin Anglosakson bir etki yaratmak adına takma isimler kullanmaları ve yabancı oyuncuları tercih etmeleriyle ilgilidir (Curti, 2015: 4).

4 Korku sineması alt türleri için birçok farklı sınıflandırma yapılmıştır. Cherry'nin yapmış olduğu sınıflandırma (2009: 6) büyük ölçüde tatmin edicidir ve bu sinıflandırmada gotik film, korku sineması alt türleri içerisinde kendisine yer bulmuştur.
} 
devasa bir zırh, her yanı örümcek ağlarıyla örülü eşyalar; portreler, şamdanlar, ahşap sandalye ve masalar, kurumuş çiçekler, vazolar, mızraklar ve hatta bir taht. Mekân, bu boş haliyle dahi ürkütücüdür. Öyle ki Foster kendi görüntüsünden bile ürker. Ama kendisini telkin eder: 'Kendini bu atmosfere kaptırma, bu tuhaf görüntülerin bir açılaması olmalı.' Bu süre zarfında Foster kendisini tehlike altında hissetmez; korku ensesinde değildir henüz. Kendince güvenli bir alandadır ve yüce hissinin ortaya çıkabilmesi için ön koşul olan güvenli alana ya da mesafelilik ilkesine sahiptir. Her şey onun yüce bir deneyim yaşamak istemesiyle uyum içindedir. Seyirci (eğer birazdan kötü şeyler olacağını varsaymıyorsa tabii) ile karakter yüce hissi özelinde bu ana dek benzer konumlardadır. Foster ne görüyorsa seyirci de aynısını görüyordur ve ikisi de güvenli konumdadır. Benzer bir şekilde, Foster şatonun bahçe kapısından girdiğinde, kamera alt açıdan karanlıkta, sisin arasından tüm ihtişamıyla göğe yükselen şatoyu gösterir bize. Foster ise onun karşısında çok küçüktür. Şatonun muazzam büyüklüğü mutlak bir büyüklükmüş gibi kendini hissettirir. Burada matematik yüce hissini oluşturan bir eziciliği vardır şatonun. Ürkütücü ve devasadır, alt açıyla yapılan çekim bu hissi daha da güçlendirir. Bu büyüklük hem Foster'ın hem de seyircinin matematik yüceyi hissetmesine imkân verir. Çünkü ortada henüz doğrudan maruz kalınan bir tehlike bulunmamaktadır. Ancak seyirci ile Foster'ın güvenli alanda olmaları ile ilgili ortaklık, Foster'ın şatonun ölü sakinleri ile karşılaşması ve onlar tarafından öldürülme tehlikesini hissetmesi ile birlikte bozulur. Bu andan itibaren artık güvenli alan / mesafelilik ilkesi Foster için yok olur. Artık Foster için salt korku ve dehşet hissi vardır. Bu his de filmin sonuna dek onun ensesindedir. Seyirci içinse güvenli alan yok olmaz. O hala perdenin ya da ekranın başındadır. Dolayısıyla seyirci yüce hissini yaşamaya devam etme şansına sahipken, Foster bu şansını kaybetmiştir. Bu nokta bizi asıl meselemize taşıyor.

Korku filmleri ya da filmlerdeki korkutucu, dehşet ve acı hissi yaratan imajlar söz konusu olduğunda yüce hissinin iki şekilde gerçekleştiğini söylemek mümkündür. İlk durum bütün süreç boyunca seyirci, bir yere kadar da karakter ile ilgilidir. Seyirci, böylesi imajlar, sahneler ve sekanslar karşısında korunaklı, mesafeli bir konumda yer aldığından bizzat tehlikenin muhatabı değildir. Korkuyu ensesinde hissetmez. Filmde, ölülerin son zamanlarını yaşadıkları anın tekrar sahnelendiği imajlarda, bu zamanlarda gezinen Foster'ın, tanık oldukları (yaşananlar sırasında olayın içerisindeki kişiler Foster'1 göremez; başka bir zaman boyutundadırlar onlar; dahası artık ölüdürler) karşısındaki korku ve dehşet hissi yüce ile ilişkilendirilemez. Foster, şatoda bir zamanlar yaşanan cinayetlere ve trajediye tanık olur; hayaletlerin birbirlerini her sene olduğu gibi yılın bu gününde de tekrar öldürdüklerini görür. Kendisi de öldürülme tehlikesi ile karşı karşıyadır. Artık kan ter içinde, korku ve dehşet hissiyle oradan oraya savrulmaktadır. Mantıklı düşünebilme yetisini yitirmiştir. Blackwood ile girdiği bahsi kaybettiğini itiraf edip haykırmaktadır. Artık gördükleri karşısında hiçbir türlü sentezi kuramamaktadır. Afallamıştır, korkmuştur. Ama yüce hissini üreten mesafelilik ilkesinden de mahrumdur. Dolayısıyla hissettiği salt dehşet ve korkudur. Negatif de olsa, herhangi bir haz durumu söz konusu değildir. Yüce hissi, filmi yer yer Foster'in gözünden seyreden, yer yer de Foster'ı izleyen seyirciye bahşedilmiştir. Korkunun ve dehşetin yarattığ 1 estetik hazzın ya da negatif hazzın tadını ancak seyirci çıkarabilir. Seyircinin bu imajlarla yaşadığı karşılaşma Kant’ın dinamik yüce olarak adlandırdığı yüce tipine karşılık gelir. 


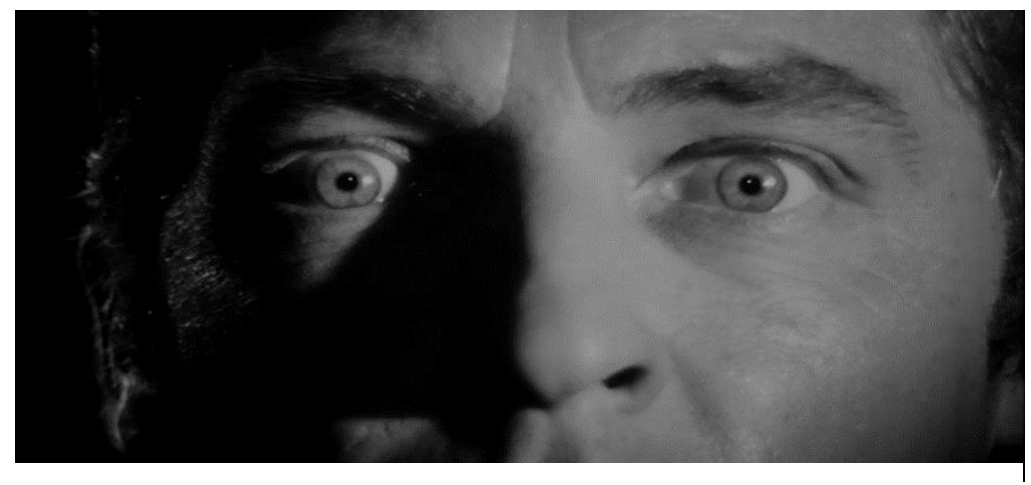

Görsel 1: Foster'ın, güvenli konumunu kaybetmesinin ardından yaşadığısalt korku ve dehşet hissini yansıtan yüzünün yakın plan çekimi

Yine, Blackwood şatosunun ölü sakinlerinden Dr. Carmus'un yaşadıklarına da aynı şekilde tanık olan Foster, Carmus'un evin yer altı mahzeninden gelen sesleri takip edip, karanlık ve örümcek ağlarıyla kaplı koridorlardan geçerek, gizli bir toplu mezarlığa ulaştığını görür. Burada, sesin kaynağı olduğunu düşündüğü bir mezarlığın kapağını ittirerek açar. İçinde çürümüş bir ceset vardır. Kuşkusuz, "cesetlerden korkmak birçok kültürün özelliğidir" (Davenport-Hines, 2005: 276). Bu cesedin örümcek ağlarıyla örülü, çürümüş görünümü de hem seyirci hem de Carmus için oldukça ürkütücüdür. Ancak dahası, bu ceset nefes almaktadır. Carmus dehşete düşer. Ama bu his de elbette yüce değildir. Carmus da bu an mesafelilik ilkesinden yoksundur. Hatta ensesinde hissettiği korku ve dehşet o kadar büyüktür ki bu his onun ölümüne sebep olur. Mesafelilik ilkesine sahip olan, ekran ya da perde önündeki seyircidir. Yüce hissinin yarattığı negatif haz duygusu seyirci için geçerlidir. Dahası; cesedin detay planlarla verilmiş görüntüsü zaten korkutucu iken bir de nefes alışını görüyor oluşumuz bu hissi alabildiğine arttırır; sınırlarımızı zorlar. Sentezi kurmak artık imkânsızdır. Salt korku ve dehşet hissi Carmus'u öldürürken, kendi güvenli alanlarında bu hislere kapılan seyirciyi negatif bir haz olarak dinamik yüce ele geçirir.

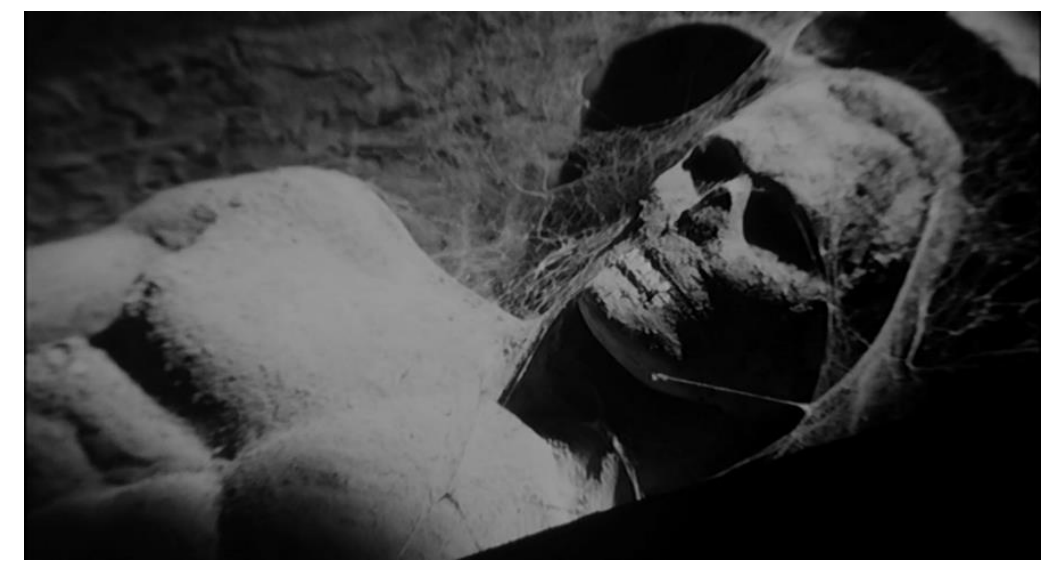

Görsel 2: Tabutun içindeki örümcek ağlarıyla örülü, çürümüş ama aynı zamanda nefes alan cesedin görüntüsü Carmus'u öldürürken, güvenli konumdaki seyirciye negatif bir haz duygusu verir.

Korku filmlerinde yücenin hissinin gerçekleştiği ikinci durum ise yücenin sinematografik sunumudur. Burada, tek başına görüldüğünde yüce hissi yaratmayacak bir sahnenin ya da bir olayın, filmik evrende kurgu ve montaj tekniklerine ya da bir takım işitsel unsurlara 
başvurularak bir yüce hissi oluşturabilmesi söz konusudur. Allison, romantik manzara resimleri ya da gotik romanlar gibi sanat biçimlerinde bir şeyin yüce olarak betimlenmesiyle, aynı zamanda bir yüce duygusu uyandırmanın amaçlandığını söyler. Dolayısıyla bu tarzdaki eserler betimledikleri şeyi sadece "beğeniye uygun bir şekilde" betimlemezler. Aynı zamanda yüce hissi yaratacak şekilde betimlerler (Akt. Altuğ, 2007: 267). Benzer bir durum sinemanın kendine özgü imkânları ile de yaratılabilir. Filmde, şatodaki hayaletlerin ölmeden önceki son anlarını tekrar yaşadıkları balo sahnesinin gelişimi bu açıdan dikkat çekicidir. Önce çan sesleri duyulur. Ardından şatonun çürümüş, örümcek ağlarıyla kaplı, karanlık, sessiz ve boş olan büyük salonu birden aydınlanır ve dans eden insanların bulunduğu bir balo salonuna dönüşür. Foster salonun bu dönüşümüne bizzat tanık olur. Aydınlık bir salonda eğlenen, dans eden insanların bulunduğu bir film sahnesi tek başına keyif ve huzur verici iken, böylesine bir geçiş ile ürkütücü bir hal almıştır. Burada yüce hissini bizzat imajların kendisinden değil, bu iki imaj arasındaki ilişkiden; başka bir deyişle montajın gücünden doğar. Dolayısıyla burada tek başına yüce hissi yaratması pek mümkün görünmeyen imajların ve olayların, sinematik imkânlar aracılığılla (bu sahnede montaj ile) yüce olarak sunumu söz konusudur.

Yücenin sadece görme duyusuyla değil, diğer duyularla da kavranabileceğine ilişkin düşüncelerine ve işitme duyusunun da bunlardan birisi olduğuna, Burke'ün yüce kavrayış1 tartışılırken yer verilmişti. Korku filmlerinde, özellikle kadraj-dışı ses kullanımı, işitme duyusu ile kavranabilecek bir yüce hissinin oluşmasına imkân verebilir. Kendi kendine sertçe kapanan kapıların çarpma sesleri, gıcırtıları, devasa bir saatin tik-tak'ları şatoya hâkim sessizliği bozan, korkutmaya ve yüce hissi yaratmaya yönelik kadraj-dışı unsurlar olarak düşünülebilir. Bu tarz unsurlar, bilindiği gibi korku filmlerinde sıkça başvurulan motiflerdir. Karanlık ve sessiz bir ortamda - ki böyle bir ortam terk edilmiş gibi görünen bir şatoysa daha da etkili olur - aniden duyulan, nereden geldiği belli olmayan sesler hem karaktere hem de seyirciye korku hissini yaşatmaya yöneliktir. ${ }^{5}$ Yinelemek gerekirse, sinema söz konusu olduğunda, seslerin bu tarzda kadraj-dışı kullanımı yüce hissini yaratan bir etkiye sahip olabilir. Bununla birlikte; sesin korku hissi yaratabilmesi için, aniden ve şiddetli ya da tekinsiz bir şekilde aralıklarla tekrarlanacak şekilde duyulmasına gerek de yoktur. Söz gelimi, minimal bir piyano sesi normal koşullarda büyük ihtimalle huzur verici bir his yaratacakken ve 'güzel' olanla ilişkilendirilebilecekken, filmde böylesi bir sesin karanlık ve sessiz; dahası kimsenin yaşamadığı düşünülen eski bir şatoda duyulması tam tersi bir etki yaratacaktır: korku ve dehşet hissi. Benzer bir şekilde, kıkırdayan bir çiftin sesleri de normal koşullarda onların mutlu olduğuna kanaat getireceğimiz bir unsurken ve yine bu sesleri işitene de mutluluk hissi verebilecekken filmdeki ortamda korku ve dehşet hissi yaratabilmektedir. Bu sesler Foster' in şatoya girmesinden az sonra, daha şatonun ölü sakinleri ile karşılaşmamışken duyduğu ve onunla birlikte seyirci olarak bizim de duyduğumuz seslerdir. Bu sesler, halen kendisini güvenlikte hisseden Foster'ı korkutmakla birlikte, zaten kendi güvenli ortamında bulunan

\footnotetext{
5 Sessizliği bozan, aniden bir anlığına duyulan yüksek sesler korku filmlerinde seyirciyi yerinden zıplatmayı (jumpscare) amaçlar. Burada hem karakter hem de seyirci benzer bir etki yaşar. Bununla birlikte jumpscare etkisi filmik evrende yer almayan müzik gibi seslerle de yaratılabilmektedir. Karakterin duymayıp seyircinin duyduğu, yaylıların birkaç notalık iç gıdıklayıcı sesi ya da piyanonun tuşlarına güçlü vuruşlar doğrudan seyirciye yöneliktir ve karakter ile seyirci arasındaki ortaklığı bozarlar.
} 
seyirciyi de korkutmaya yöneliktir. Ancak burada da yüce hissini yaratan sesin kendisi değil (çünkü o müzik ya da o kıkırdama sesleri, tek başına böyle bir etki yaratmaktan uzaktır; hatta tam tersi bir etki yaratır), o sesin yayıldığı ortam ile ilişkisinden doğan bir korkudur. Böylece sadece kurgu ve montaj teknikleri aracılığı ile değil, sinematik ses kullanımı sayesinde de yücenin sinematografik sunumundan söz edebilmek mümkün hale gelir.

\section{Sonuç}

Burke ve Kant'ın yüce kavrayışlarının, sinemada korku, dehşet ve acı gibi pejoratif duyguların yarattığı estetik hazzı anlamlandırmak adına oldukça kullanışlı olduğunu söylemek mümkündür. Bu korku, dehşet ve acı hissinin estetik bir hazza, yani yüce hissine yol açabilmesi için güvenli bir alana ihtiyaç vardır. Seyirci sinema salonunda ya da ekran başında bu güvenli alana her zaman sahiptir. Filmik evrende yer alan karakter ise tekinsiz ortamlarda bir tür macera ararken ve henüz tehlikeyi ensesinde hissetmezken, kendisinin güvenli bir alanda olduğunu varsayar. Ancak karakter bizzat tehlikenin muhatabı olduğunu ve can güvenliğinin tehdit altında olduğunu anladığında artık yüce onun için geçerli değildir. Hissettiği salt korku, dehşet ve acıdır. Bu noktada yüce hissinin olanaklılığı seyirci için film boyunca sürerken, karakterin durumu bu noktada artık ondan ayrılır. Bu nitelik korku, dehşet ve acı hissi yaratmayı amaçlayan sinematik imaj, sahne ve sekanslardan doğan 'negatif' hazzı açıklayan ilk durumdur. İkinci durumda ise tek başına korku, dehşet veya acı hissi üretmeyen, hatta tam tersine mutluluk hissi verebilecek ve güzel olanla ilişkilendirilebilecek imajların (eğlenceli bir balo sahnesi gibi) kendisinden önce ya da sonra gelen imajla girdiği ilişkiden üretilen yüce hissi ve yine tek başına korku, dehşet veya acı hissi üretmeyen işitsel unsurların (müzik ya da neşeli gülüşmeler gibi), işitildikleri ortama veya filmik zamana bağlı olarak yarattığı yüce hissi ile ilgilidir. Bu durum yücenin sinematografik sunumudur.

İlk durum ve ikinci durum bir film içerisinde birçok kez aynı anda, birlikte var olabilirler. Bununla birlikte başkaca çalışmalarda konu ile ilgili olarak yüce daha farklı ve çeşitli bakış açılardan da sinematik korku, dehşet ve acı ile ilişkilendirilebilir. Ayrıca bu çalışmada örnek çözümleme tek bir film ile sınırlı tutulmuştur. Dolayısıyla tek bir film çözümlemesi üzerinden yapılan bir genellemenin oldukça iddialı olacağını da söylemek yanlış olmaz. Korku, dehşet ve acının sinemada nasıl oluyor da estetik bir haz talebi ile seyredildiğini yüce kavrayışı üzerinden daha geniş bir kapsama oturtabilmek adına farklı tür ve alt türlere ait film örneklerinin çözümlenmesi mutlaka faydalı olacaktır.

\section{Kaynakça}

Altuğ, T. (2007). Kant Estetiği. İkinci Baskı. İstanbul: Payel.

Botting, F. (1996). Gothic. London: Routledge.

Burke, E. (2008). Yüce ve Güzel Kavramlarımızın Kaynă̆ı Hakkında Felsefi Bir Soruşturma. Çev. M. Barış Gümüşbaş. Ankara: BilgeSu.

Cherry, B. (2009). Horror. London and New York: Routledge 
Curti, R. (2015). Italian Gothic Horror Films, 1957-1969. Jefferson, North Carolina: McFarland \& Company.

Davenport-Hines, R. (2005). Gotik: Aşırılık, Dehşet, Kötülük ve Yıkımın Dört Yüz Yılı. Çev. Hakan Gür. Ankara: Dost.

De Quincey, T. (2013). Güzel Sanatların Bir Dalı Olarak Cinayet. Çev. İsmet Birkan. Üçüncü Baskı. İstanbul: İletişim.

Deleuze, G. (2007).Kant Üzerine Dört Ders. Çev. Ulus Baker. İstanbul: Kabalcı.

Ferry, L. (2012). Homo Esteticus Demokrasi Çağında Beğeninin İcadı. Çev. Devrim Çetinkasap. İstanbul: Pinhan. İdea.

Kant, I. (2016). Yargı Yetisinin Eleştirisi. Çev. Aziz Yardımlı. Üçüncü Baskı. İstanbul:

Kant, I. (2017). Güzellik ve Yücelik Duyguları Üzerine Gözlemler. Çev. Ahmet Fethi. İkinci Bask1. İstanbul: Hil.

Odell, C., Le Blanc, M. (2011). Korku Sineması. Çev. Ali Toprak. İstanbul: Kalkedon.

Oskay, Ü. (2014). Çă̆daş Fantazya. İstanbul: İnkılap.

Schiller, F.V. (2008). Schiller. Çev. ve Haz. Gürsel Aytaç. Ankara: Doğu Batı.

Scognamillo, G. (2006). Canavarlar Yaratıklar Manyaklar. İstanbul: +1 Kitap.

Scognamillo, G. (2014). Korkunun ve Dehşetin Kapıları. İstanbul. Bilge Karınca.

Tunalı, İ. (2010). Estetik. On İkinci Bask1. İstanbul: Remzi Kitabevi. 